The Echo of Things 
OBJECTS/HISTORIES - CRITICAL PERSPECTIVES ON ART, MATERIAL culture, and representation - A series edited by Nicholas Thomas

Published with the assistance of the Getty Foundation. 


\section{The Echo of Things}

THE LIVES OF PHOTOGRAPHS IN THE SOLOMON ISLANDS

Christopher Wright

Duke University Press - Durham \&London - 2013 
(C) 2013 Duke University Press

All rights reserved

Printed in the United States

of America on acid-free paper @

Designed by Amy Ruth Buchanan

Typeset in Garamond Premier Pro and

Meta by Tseng Information Systems, Inc.

Library of Congress Cataloging-in-Publication Data

Wright, Christopher (Christopher J.)

The echo of things : the lives of photographs in the

Solomon Islands /

Christopher Wright.

p. cm. - (Objects/histories)

Includes bibliographical references and index.

ISBN 978-0-8223-5496-3 (cloth : alk. paper)

ISBN 978-0-8223-5510-6 (pbk. : alk. paper)

1. Photography in ethnology - Solomon Islands.

2. Solomon Islands - Pictorial works. 3. Solomon

Islanders - Pictorial works. I. Title. II. Series:

Objects/histories.

GN347.W73 2013

$305.80099593-\mathrm{dc} 23$

2013020979 
For Joanna, Beinn and Evan, and for my parents, with love. 
